\title{
Based on SWOT Analysis of Patriotism Education in Colleges and Universities in the Times of Media Convergence
}

\author{
Meixue Wang \\ Faculty of Education, Guangxi Normal University, Guilin 541004, China
}

\begin{abstract}
As an essential base to train high-quality talents, colleges and universities are the central position of the dissemination of patriotism education, as well as the wrestling field to introduce various ideologies. With the coming of the era of integrated media, the advantages of traditional media and new media are fully integrated and brought into full play, which provides a unique historical opportunity for universities to carry out patriotic education, but also brings unprecedented impact and challenges. This paper analyzes this with SWOT analysis method. Colleges and universities should make good use of the advantages of carrying out patriotic education in colleges and universities, establish the concept of campus media integration development, train the talented team of campus media integration development, make full use of the integrated media platform to create an ecological environment in line with the work of patriotism education in colleges and universities, innovate the path of patriotism education in colleges and universities.
\end{abstract}

Keywords: Media Convergence, Patriotism Education, SWOT analysis.

\section{Introduction}

Patriotism is the heart and soul of the Chinese nation, the most critical spiritual wealth of the Chinese government, and a powerful spiritual driving force for the Chinese people and government to safeguard national independence and dignity. Patriotism and national unity are the sources of strength for the Realization of the Chinese dream of national rejuvenation by the sons and daughters of the Chinese nation in the new era[1]. Carrying out patriotism education in colleges and universities is of great significance to strengthen the patriotic enthusiasm of college students and realize the cohesion of the Chinese nation and the consciousness of national community. However, with the development of Internet technology, mobile Internet has become the primary channel of information transmission, the fusion of traditional media and new media development become the trend of The Times, on the premise of product, as the means, to lift the combination of the advantages of traditional media and new media, to realize the optimization of media resources use efficiency "melting media" arises at the historic moment. According to the 48th Statistical Report on Internet Development in China, the number of Internet users in China reached 1.011 billion by June 2021, with the Internet penetration rate reaching $71.6 \%$ and the number of mobile phone users reaching 1.007 billion. Among them, those aged 6-19 and 20-29 accounted for 15.7\% and $17.4 \%$ of China's total Internet users, respectively[2]. In the context of the media era, it is difficult for teenagers to identify and screen key effective information in the face of complicated information on the Internet, which undoubtedly brings profound influence and challenges to patriotic education in schools. Colleges and universities how to use financial media development philosophy and platform advantage, increase of patriotism education through the research of the development of the media fusion of integration and use, promote the innovation in the path of the patriotism education in Colleges, vivid and speak good Chinese story, patriotic, dissemination of the mainstream values, is the current work to carry out patriotism education in colleges and universities is an important issue.

\section{The Responsibility of Patriotism Education in Colleges and Universities Under the Background of Media Era}

In November 2019, the CPC Central Committee and The State Council issued the Outline for the Implementation of Patriotic Education in the New Era, making new plans and arrangements for the creation of patriotic education in the new era and putting forward new guidance and requirements for the work of patriotic education in higher education[1].The outline points out that patriotism education in the new era should focus on young people and make full use of the integration of mass media such as newspapers, radio, film and television with the theme of Internet patriotism to create an intense atmosphere for patriotism education in the new era. Chinese President Xi Jinping has pointed out that in publicity and ideological work, we must follow the trend, act in accordance with the direction and accelerate the integrated development of the media, expand and strengthen mainstream public opinion, and consolidate the common ideological foundation for the concerted efforts of the whole Party and the whole people[3]. Patriotism education in colleges and universities should also promote the interaction and integration of campus media, adhere to the "content is king", "innovation first" and "integration first", play a synergistic effect, promote the limited propaganda resources better, and effectively spread the information of patriotism education to the majority of college students.

Media era, smartphones, iPad, computers, 5G of iterative development and Weibo, WeChat, trill, quickly since the media platforms such as blessings, college students in learning knowledge, access to information and social ways have changed. The complicated network of an ideology of college students' ideological understanding, values and behavior has caused a certain impact. Therefore colleges should speed up the construction of integrated media centers, adhere to the mainstream public opinion position, guard 
against the ideological risk of colleges and universities, actively guide students' patriotism, and implement the fundamental task of moral education and human education. At the same time, in the context of the media era, colleges should also cultivate and exercise students' literacy and ability to actively adapt to the development of media. Colleges should not only carry out patriotism education with the help of the media platform, but also guide and encourage students to learn the development concept and advanced technology of media, to cope with the challenges brought by media and enhance students' comprehensive quality in the context of media era.

\section{SWOT Analysis of Patriotism Education in Colleges and Universities Under the Background of Media Era}

\subsection{Advantages of Patriotism Education in Colleges and Universities in the Context of Media Era (S)}

3.1.1 Media breaks the time and space limitation of traditional patriotic education

The traditional patriotic education in colleges and universities is mostly face-to-face education mode, which is limited in time and space to varying degrees. In the era of integrated media, patriotism education in colleges and universities can create an open, interactive and comprehensive integrated media publicity environment of "integrated resources, integrated content, integrated publicity and integrated interests" with the help of cutting-edge Internet technology. Patriotism education in higher education breaks the time and space limitation of traditional education model to a great extent[4].

3.1.2 Media provide a more authoritative and authentic platform for information disclosure and publicity of colleges and universities

In the media era, the public opinion environment of "everyone is a spokesman" has gradually formed. Faced with overwhelming and mixed information on the Internet, college students tend to get lost in the vast ocean of information and find it difficult to distinguish the truth from the falsity of statement. Media not only provides a broader education platform and rich educational resources for universities to carry out patriotism education, but also provide a good platform for universities to make their voices heard on and better enhance the information openness and the authority and authenticity of propaganda.

3.1.3 Melt media downplay patriotism education subject relationship

In the traditional education model, the educator is the subject and the educatee is the object. In the process of receiving education, the indoctrination education fails to fully consider the actual needs and psychological development of college students. According to the viewpoint of reception aesthetics, "the reader is the subject", and the works should start from the audience. In the context of the media era, students can freely choose the content they are interested. Therefore, colleges and universities should change the role concept, dilute the relationship between educational subjects, reduce the lecturing color, cater to the psychology and acceptance degree of college students, and enhance effective communication.

\subsection{Disadvantages of Patriotism Education in Colleges and Universities in the Context of Media Era (W)}

\subsubsection{The quality of campus media information release is not high}

"Content is king" is the basis for media to enhance competitiveness. Only by improving the quality of information content can colleges and universities attract students' attention and finally achieve the goal of patriotism education. However, at present, campus media information homogenization is serious, lack of professionalism, content quality is uneven, the reasons are, on the one hand, campus media shoulder the responsibility of building campus culture, so the scope and ideas of topic selection and materials are relatively narrow. On the other hand, campus media are primarily operated and managed by teachers and students and lack professional training in media operation.

3.2.2 Media is easy to cause waves of public opinion and negative thoughts

Although college students have come of age, their cognitive ability and level are not mature enough, their ideology is prone to deviation, and their outlook on life and values are vulnerable to the impact of alarming ideological trends[5].The media is secretive, and network information publishers use anonymity to publish extreme and irrational views and public opinions, causing the patriotic enthusiasm of college students to be taken advantage of by interested people, and extreme and irrational patriotic behaviors appear. Finance media background, college students in the face of this distinction, the detailed information easily affected by false claims, these wrong ideas in speech will warm fermentation media environment, form the public opinion, eventually shake the status of the mainstream ideology of colleges, and even cause negative thoughts and political education work of colleges in a dangerous situation of a rival.

\subsection{Opportunities to Carry out Patriotism Education in Colleges and Universities under the Background of Media Era (O)}

3.3.1 Media construction has been paid more and more attention by colleges and universities

China university new media union witnessed the establishment and development of China's colleges and universities the course of the construction of new media. The league has more than 100 regional college campus media members, union at the same time is also responsible for preparing the annual session of the campus BBS new media communication, provide training for university new media operations, ensure the healthy development of the campus media. At present, some colleges and universities are building media centers for the integration of traditional media and new media with the help of campus broadcasting stations, campus networks, WeChat official accounts, Weibo, YiBan and other 
platforms. Universities attach great importance to the construction of balanced media, which is also a new historical opportunity for colleges and universities to use harmonious media to carry out patriotic education.

\subsubsection{Continuous optimization of media operation environment}

With the continuous development of Internet technology, the $5 \mathrm{G}$ era has arrived, the constant optimization of campus network conditions, the gradual reduction of network charges, and the widespread popularity of mobile Internet devices, all of which provide the development foundation for universities to use financial media to carry out patriotism education.

\subsubsection{College students' new media literacy has been significantly improved}

"New media literacy" refers to the more extensive and better social network that individuals build to adapt to the new media environment and changes in social relations under the background of the Internet revolution, the mobile revolution, and social network revolution, as well as the new abilities that individuals should master, including knowledge, skills, emotions, attitudes and values. In recent years, scholars have conducted many studies on the media literacy of college students and indicated that the level of new media literacy of college students is in a state and trend of steady improvement. Most college students can skillfully release information through new media platforms. The ability to hold a wait-and-see attitude towards false information on the Internet or to distinguish truth from falsehood, as well as the willingness to participate in and deal with social affairs through online channels, has been constantly enhanced.

\subsection{The Threat of Patriotism Education in Colleges and Universities under the Background of Media Era (T)}

\subsubsection{The impact of new media platforms emerge endlessly}

The so-called "survival of the fittest", the elimination of a batch of media platforms, has created the current prosperity of new media platforms. Trill, quickly, such as the rapid rise of the short video media, attracted a large number of users, these have high user community media platform in user stickiness and commercial value continuously from weak media market and space, use a melting media platform to carry out patriotism education in universities will face competition from other new media platforms and threats.

3.4.2 The concept, technology and system of campus media operators need to be updated

The main operation team of campus media is composed of teachers and students from the publicity department and student work department. The work input of Chengdu is far less than that of ordinary social media, and it isn't easy to timely adapt to the needs of the development of the situation. At the conceptual level, the use of media to carry out patriotism education should be adapted to students' needs and physical and mental development as the first principle. We should follow the trend and make the best of the situation. At the technical level, media publicity work requires continuous learning and practice. Still, the operation team of student editing and editing is highly mobile and unstable due to reasons such as entering college, and the level of editing and editing cannot be continuously improved, so the development of integrated media is complex. At the institutional level, because there is no profit source for campus media, and there is no internal media operation assessment and reward and punishment mechanism, it isn't easy to mobilize students' enthusiasm and creativity to participate in campus media construction.

3.4.3 The authenticity of information is difficult to distinguish, and there is a lack of supervision and control

In the traditional patriotic education model, the educational environment is relatively closed and the whole educational process is highly controllable. Integrating media era background, however, the increase of transmission makes a variety of information at the same time, also with a lot of low-quality, false, irresponsible remarks, college students can't distinguish the receives all the authenticity of information, if not be directed, easy to form the bad patriotism faith, irrational or extreme patriotism, disturbing social order, Damage the image of the country. At present, the country still has great deficiencies in information release and governance, a lack of relevant regulations on information release supervision.

\section{Analysis on the Path of Patriotism Education in Colleges and Universities Under the Background of Media Era}

On December 8, 2016, Chinese President Xi Jinping pointed out at the National Conference on Ideological and Political Work in higher education that "new media and new technology should be used to make work more active, promote the integration of traditional advantages of ideological and political work with information technology, and enhance the sense of The Times and appeal"[6]. SWOT analysis of patriotism education in Colleges and Universities under the background of integrated media era, this study clarified the advantages, disadvantages, opportunities, and challenges of using "fusion media" to carry out patriotism education in colleges and universities, and found that the influence of fusion media is two-sided. If properly used, avoiding risks can significantly improve the effectiveness of patriotism education in colleges and universities, to reasonably exploit the strengths and circumvent the weaknesses of patriotism education in colleges and universities under the background of the media era.

\subsection{Reshape the Work Concept and Promote the Docking and Integration of Media and Patriotism Education in Colleges and Universities}

Traditional media and new media complement each other's advantages, creating a better platform for college students to express their feelings. In contrast, new media has more advantages in students' independent choice and free expression of information. In this case, to promote financial media and patriotism education when the priority of the docking and fusion of the idea of traditional patriotic 
education work, the first thing to affirmation, respect students' subject status, combining the dominant education and recessive education positive publicity and education work, promote the "force-feeding" education to "infiltrating type" the transformation of education, Truly achieve the educational goal of serving students and promoting students' growth. Secondly, we should pay attention to respect students' diversified needs and individual differences, constantly improve the content construction of patriotism education, enhance the attractiveness and appeal of education content, create a standard discourse system with students, and make patriotism education spring breeze rain, moistening things silently. Finally, we should take the initiative to deepen the integration of traditional media and new media, and use the media platform to listen to the aspirations of students, reflect the demands of students, and provide a platform for the growth of college students.

\subsection{Strengthen the Construction, Development and Application of Financial Media Platform}

University financial media construction should be supported by advanced technology, Internet, wireless communication, large data, cloud computing, interactive intelligence as one of the integration platforms, implement personalization and intelligent push transmission of mobile data services, through the campus radio station, newspaper, website, WeiBo, WeChat public number, easy class, such as "learning power platform interaction and fusion, Let patriotism education permeate every corner of the campus". Through the construction of micro-courses, MOOC, and other curriculum resources platforms to increase the way of students to obtain knowledge and information, to create an excellent patriotic education learning atmosphere. Use VR, H5, micro-video, micro-film, micro-animation, and other new forms of publicity to create vivid and interesting patriotic education works. In addition, the integration of student comprehensive evaluation and evaluation with the media platform attracts student flow. It makes the media platform become an vital position to guide the ideological development and growth of college students[7].

\subsection{Strengthen the Supervision of Media Patriotism Education and Improve the System Guarantee Mechanism}

Land "outside" network is not method. Both have to respect Internet users free speech, but also to maintain the good order of the network society, so to strengthen the financial media platform and the regulation of the patriotism education, scientific design, implementation, network information back, adhere to the "source control", guarantee the correct development direction of the media and the main melody of patriotism education[8]. We must firmly control uncivilized, unhealthy and irrational online speech and actions and never allow them to prevail. At the same time, we should strengthen legislation on media supervision, improve laws and regulations on information services, safety protection, and social management. The construction of media platforms and patriotism education work can run soundly on the track of the rule of law.

4.4 Give Full Play to the Main Channel of Classroom
Teaching and Enrich the Carrier of Patriotism Education Practice

The Implementation Outline of Patriotism Education in the New Era points out that the spirit of patriotism should run through the whole process of school education, give full play to the role of classroom teaching as the main channel, set up courses combining patriotism education with philosophy and social science-related majors in colleges and universities, and increase the proportion of patriotism education content. Colleges and universities to carry out patriotism education to take advantage of college curriculum resources, strengthen the ideological and political theory course teachers team construction, with the help of a media platform to support and encourage the development of micro lesson, a lesson for online education curriculum resources, hold the characteristic of teenagers are in "the jointing-booting stage" justified for ideological and political theory course, completes the patriotism education. At the same time, we should organize and carry out extensive patriotic education and practice activities, adhere to the combination of online and offline, and actively promote the integration of patriotic education resources, media platforms and social practice activities[9]. By organizing students to visit the memorial hall, exhibition hall, patriotism education base and national defense education base, participating in innovation and entrepreneurship and public welfare activities, etc., constantly enrich and expand the practice carrier of patriotism education outside school. Through excavating patriotic educational resources contained in major anniversaries and historical events, commemorative activities and thematic education can be carried out. Or through sightseeing natural and cultural landscape and major projects to carry out patriotism education, through publicity, display, experience and other ways to guide college students to feel the achievements of the construction of the motherland, enjoy the fruits of development, and devote themselves to the building of a beautiful China. For example, in the "Large-scale Achievement Exhibition celebrating the 70th Anniversary of the founding of the People's Republic of China", students can visit the great course and brilliant achievements of the motherland in the past 70 years with the help of the financial media platform.

\subsection{We Should Build A Community with A Shared Future for Mankind and Foster A Rational and Inclusive National and Patriotic Mentality}

Patriotism is the basic requirement of the national of a country and the common emotion of people worldwide. So we in the promotion of Chinese national patriotism education has also asked college students in all rivers run into the sea, rational tolerant attitude to respect other countries' history and culture, respect for people from different countries choose the road of development, continue to carry forward patriotism education combined with expanding the opening to the outside world. We should uphold peace, development and win-win cooperation, build a community with a shared future for mankind, and jointly create world peace and development.

\section{Conclusion}

In the context of the media era, we should grasp the pulse of the development of The Times, speed up the integration of 
campus media platforms, and make the mainstream public opinion of patriotic education bigger and stronger. At the same time, college students should strengthen their ability to serve the country, not talk about patriotism. Colleges and universities should advocate students to adhere to the unity of knowledge and action, transform patriotic feeling into patriotic action, express patriotic feeling with rational behavior, and achieve the transformation from "I want to be patriotic" to "I want to be patriotic". Party committees and youth League committees in higher education should assume the primary responsibility, strengthen the construction and management of patriotic education positions, plan and coordinate, and implement in place. Of course, in the context of the media era, the specific approaches to carry out patriotic education in higher education are not limited to reconstructing work concepts, building platforms, strengthening supervision, enriching practice carriers, and cultivating an inclusive mentality. Financial media is a double-edged sword, which brings convenience to patriotic education in colleges and universities, but also brings instability. However, if you do not advance, you will fall back. Therefore, colleges and universities should grasp the comprehensive understanding of financial media, foster their strengths and avoid their weaknesses, make full use of the advantages and circumvent their disadvantages, and carry out work accordingly to create a new situation of patriotic education in colleges and universities.

\section{References}

[1] The CPC Central Committee and the State Council. The Implementation Outline of Patriotism Education in the New Era [N]. The Xinhua News Agency, 2019-11-12.

[2] China Internet Network Information Center. The 48th Statistical Report on Internet Development in China [EB/OL]. http://www.cac.gov.cn, 2021-09-15.

[3] Xi Jinping: Bearing in mind the overall situation, grasping the general trend, focusing on major issues, and striving to do better publicity and ideological work $[\mathrm{N}]$. People's Daily, 2013-08-20.

[4] Yue Peng, Hu Yifan, Yan Wen. Thinking and practice of college students' ideological and political education in the Era of Integration of media [J]. Think Tank Times, 2019(49).

[5] Sun Shan. Rational patriotic Education Path selection for College Students under new Media Environment [J]. Southern Journal, 2018(11).

[6] Xi Jinping stressed at the National Conference on Ideological and Political Work in Colleges and Universities that the ideological and political work should run through the whole process of education and teaching to create a new situation in the development of China's higher education [N]. People's Daily, 2016-12-09.

[7] Cong Liang. Challenges and Countermeasures of Ideological and Political Education in Colleges and Universities in the Era of Media Integration [J]. Ideological and Theoretical Education, 2019(11).

[8] Li Wensheng. The Path of Patriotism Education from the Perspective of New Media [J]. Young Reporter, 2017(32).
[9] Shen Qianfan. Integrating Patriotism Education into the Whole Process of College Education [N]. Economic Daily, 2019-12-25. 